J-DEPACE, Volume 3, Nomor 1, Juni 2020, Hal. 171 - 177

Tersedia online di:http://jurnal.lpmiunvic.ac.id/index.php/jpkm

\title{
INCREASING THE UNDERSTANDING AGAINST PERSONAL PRONOUN AND TO BE TO THE STUDENTS OF YPPK CHRIST THE KING 1 ELEMENTRY SCHOOL OF SORONG GRADE 6
}

\author{
Agustinus L. Masan ${ }^{*}$, Frits Gerit John Rupilele ${ }^{2}$ \\ Aram Palilu ${ }^{3}$ \\ Universitas Victory Sorong \\ liamasanagusto@gmail.com ${ }^{1 *}$, fritsrupilele@gmail.com ${ }^{2}$, \\ arampalilu1015@gmail.com ${ }^{3}$
}

\begin{abstract}
ABSTRAK
Karena bahasa inggris adalah bahasa international, maka siswa-siswi di negeri ini sudah belajar bahasa inggris sejak dini tapi apakah mereka benar-benar paham akan kata ganti orang dan kata kerja bantu (To Be)? Bahasa Inggris memang sudah di pelajari dari tingkat rendah akan tetapi pemahamn dan metode pengajaran menjadi tantangan untuk mencapai hal kecil, dan PKM ini mengarah ke hal tersebut. Akan tetapi sistem pendidikan menjadi momok bagi tahap pembelajaran bahasa inggris diberbagai tingkat pendidikan yang tidak detail. Metode yang digunakan dalam kegiatan pengabdian pada masyarakat ini adalah pengajaran Bahasa Inggris.Tahapan pengajaran terdiri dari tes awal, pemaparan materi, tes akhir, dan evaluasi. Kegiatan pengajaran Bahasa Inggris "Increasing The Understanding Against Personal Pronoun and To Be To The Students of YPPK Christ The King 1 Elementry School of Sorong Grade 6." ditujukan kepada anak-anak SD sebagai sasaran.Tingkat keberhasilan pengajaran ini ditentukan oleh adanya perbedaan pemahaman tes awal (pre-test) yang belum memadai dan pemahaman tes akhir (post-test) yang memadai mengenai personal pronoun and To Be dari siswa-siswa tersebut.
\end{abstract}

Kata kunci: meningkatkan, pemahaman,To Be, Personal Pronoun.

Because English is an international language, students in this country have learned English from an early age, but do they understand the pronouns and help verbs (To Be)? English has indeed been acquired from a low level, but understanding and teaching methods are a challenge to achieve small things, and this PKM leads to it. However, the education system is a scourge for the learning phase of English in various levels of education that are not detailed. The method used in community service activities is the teaching of English. The stages of instruction consist of preliminary tests, exposure material, final tests, and evaluations. English teaching activity "Increasing the Understanding Against Personal Pronoun and To Be to The Students of YPPK Christ The King 1 Elementry School of Sorong Grade 6." addressed to elementary school children as a target. The level of success of this teaching is determined by the differences in understanding of the initial test (pretest) which is inadequate and the knowledge of the final examination (post-test) that is adequate about the personal pronoun and To Be of these students. 


\section{Keyword: Increas, understand, To Be, Personal Pronoun}

\section{INTRODUCTION}

Language is one of the most important things in communication and it is used as a tool of communication among the nations all over the world. That is way we need to know and need to be dug for a deep understanding in it.

It is very important for us to communicate with the people all around the world, and we have to start now. We have to prepare our next generation. Nowadays, English has taught in every level of schools. Even in Sorong city, English has taught to the students from playgroup level until university. In real condition, there are so many people in Indonesia can not speak English well even if they have learned it for more than years. It is also as a causality problem because it is a foreign language.

English is very needed to the students and general, so English teacher should take an attention toward the students' competent primary the four basic skills: speaking, writing, reading, and listening. This is also important for the English teacher to promote and motivate the students to love learning and love English. Besides that, personal pronoun and $\mathrm{To} \mathrm{Be}$ is the smallest thing should be mastered. They will distinguish the sentence of verb sentence and nominal sentence. Dealing with the time, English teacher still felt difficult in how to choose the technique and media used and how to teach well. In this case, teachers have responsibility to lead the students during their learning process, and remind them for learning hard and harder. For this situation, our team makes a closer distance to the society by using our own method. Learning English is important but do not push them (the students) for a long time, and more words memorizing is not accurate because the today's students are a friend of Smartphone era. They are busy with it. Teachers have to find the answer in it.

Our serving society team saw and felt the need for motivating the children to avoid the misunderstanding during communication in English. In other hand, remind them the basic usage of personal pronoun and To Be. This is important to be learned detail so the students become usual and enjoy learning English. The Students of YPPK Christ The King 1 Elementry School of Sorong Grade 6 is chosed by the team as the representative students of Sorong City. This serving society is hoped will be done in another place also. But still 
the same "bringing the basic need of learning English and a better understanding in it is our team's motto".

Our team also realizes that personal pronoun and To Be are the primary terms which to be learned. In other side, we are allowing students to take part in teaching and learning process. Here we are trying to explain the case simply, well, and slowly in other to make easier for the students to understand. This way, the children will distinguish the error sentence in combining subject and To Be. The reason why, the serving to the society here with a given title "Increasing The Understanding Against Personal Pronoun and To Be To The Students of YPPK Christ The King 1 Elementry School of Sorong Grade 6."

\section{FORMULATION OF THE PROBLEM}

Refers to the interview making to the students of YPPK Christ the King 1 Elementry School of Sorong Grade 6 it can be concluded that understanding about personal pronoun and To Be are so poor or limited. It caused of schools are just focusing on following what are saying by the leading government. So they do as what are saying. Here are some questions as the formulation of the problem. They are as follow:

a. Did the schools make the students understand about personal pronoun and To Be?

b. How to expand the understanding and to reduce the misunderstanding of students against personal pronoun and To Be?

\section{METHODOLOGY}

The methodology of Serving the society is public education.the purpose in using this method is to build up understanding and knowledge to the public society specificly the students. Besides that, there are some stages for doing serving to the society in Elementry School students of Sorong, YPPK Christ the King 1 Grade 6 are as follow:

\subsection{Pre-Activity (Pre-Interview)}

First of all, before the teaching, our team having interview against the problem of personal pronoun and To Be at school and the way out as the solution. As to the interview finding our team conclude that understanding about the case is out of expecting. For that reason, our team has to do this teaching the material about increasing the understanding about personal pronoun and To Be to the students. 


\subsection{Main Activity}

There are the material stages which are presented in this serving the society about increasing the understanding against personal pronoun and To Be the students of YPPK Christ the king 1 elementry school of Sorong grade 6. They are as follow:
a. To Be,
b. Personal Pronoun,
c. Nominal sentence, and
d. Verb sentence

There is also a schedule of the activity about teaching English increasing the understanding against personal pronoun and To Be. The schedule is as in below:

\begin{tabular}{|c|c|c|}
\hline Hari/Tanggal & Jam & Kegiatan \\
\hline saturday, May 30 2019 & $07.30-08.00$ & Member Registration \\
\cline { 2 - 3 } & $08.00-09.30$ & Pre-interview \\
\cline { 2 - 3 } & $09.30-11.00$ & Teaching Material \\
\cline { 2 - 3 } & $11.00-11.30$ & Break Time \\
\cline { 2 - 3 } & $11.30-01.00$ & Post-interview \\
\cline { 2 - 3 } & $01.00-$ finish & Closing \\
\hline
\end{tabular}

\subsection{Post Activity (Post-Interview)}

There is also a technique where used to measure how far students' understanding and knowledge about personal pronoun ad To Be, we called as post interview. This step is the way to compare with pre interview after getting the material presentation. As to the comparison between pre interview and after getting the material presentation so can be known how far the students' understanding and knowledge about personal pronoun and To Be.

\section{FINDINGS AND DISCUSSION}

Teaching against the Students of YPPK Christ The King 1 Elementry School of Sorong Grade 6 about personal pronoun and To Be can be done in some stages. They are as follow: 


\subsection{Auxilliary Verb "To Be"}

According to Oxford Advance Learner's Dictionary states auxilliary verb verb such as be, do and have used with main verbsto show tense, aspect, voice, mood, and person. Here our concern is in person.

4.1.1 Present Simple

Am

Is

Are

4.1.2 Simple Past

Was

Were

\subsection{Personal Pronoun}

4.2.1 Personal Pronoun As Subject only

\begin{tabular}{|c|l|}
\hline Pronoun as Subject & \multicolumn{1}{|c|}{ Meaning in Indonesian } \\
\hline I & Saya \\
You & Engkau \\
$\mathrm{He}$ & Dia laki-laki \\
She & Dia perempuan \\
It & Dia benda \\
$\mathrm{We}$ & Kami/kita \\
They & mereka \\
\hline
\end{tabular}

4.2.2 Personal Pronoun and To Be

\begin{tabular}{|c|c|l|l|}
\hline $\begin{array}{l}\text { Subject } \\
\text { pronoun }\end{array}$ & Auxiliary verb ( To Be) & Indonesian sentence & $\begin{array}{c}\text { Translate into } \\
\text { English }\end{array}$ \\
\hline $\mathrm{I}$ & Am & Saya adalah Timor. & I am a Timor. \\
\hline $\mathrm{He}$ & is & $\begin{array}{l}\text { Saya adalah laki-laki. } \\
\text { Saya adalah perempuan. }\end{array}$ & $\begin{array}{l}\text { He is a man. } \\
\text { She is a woman. } \\
\text { It is an island. }\end{array}$ \\
It & & Itu adalah pulau. & Kita adalah satu. \\
We & are & Engkau pintar. & You are clever. \\
You & & Mereka baik. & They are nice. \\
They & &
\end{tabular}




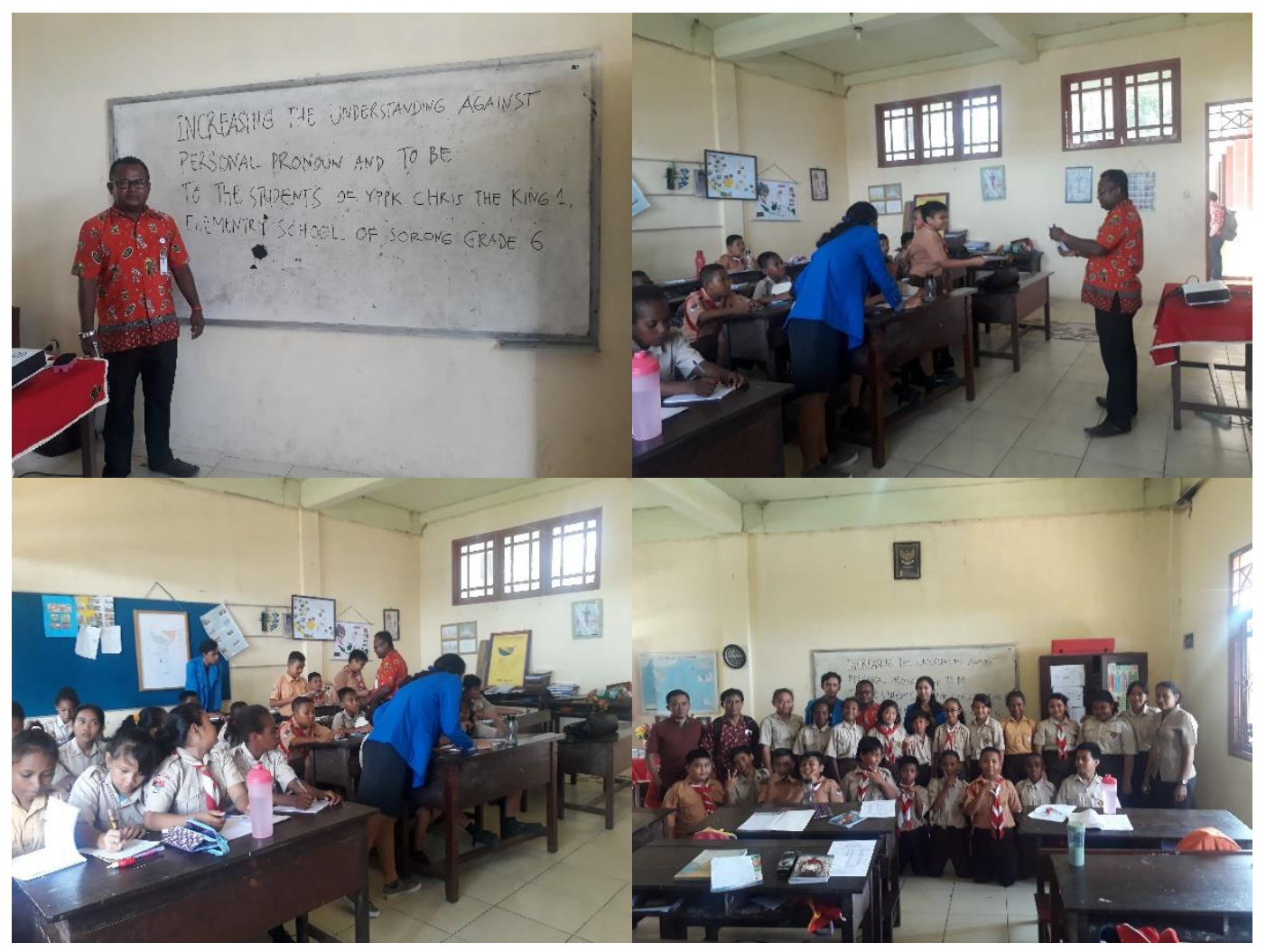

Gambar 1. Situation during the teaching

\section{CONCLUSION}

Teaching students from elementary level, our serving team to the society can concluded that students from a different economic background and knowledge level are very happy and satisfy with our increasing the understanding against personal pronoun and To Be teaching. Why they were satisfied. They were also satisfied because the differences between nominal sentence and verb sentence never explained well and give full attention about this so the students did not understand at school. More than that, they never had well explanation about them. In other words teachers at school did not give a special time for the students to understand it. So that, our team gave a special explanation, time for the students. So they got the main point of our teaching and misunderstanding can be reduced during constructing sentences in English by the students. In other side, this is very affected the children's interest against personal pronoun and $\mathrm{To} \mathrm{Be}$ and minimize the errors. So as final words, for this serving to the society is expacting and struggling in other the activity like this can be done for the future. 


\section{BIBLIOGRAPHY}

Murphy, Raymond. 2007. Essential Grammar in Usage. Third edition, England: Cambridge University Press

Greenbaum, Sidney, dkk. 1990. Student's Grammar of The English Language. England: Pearson Education Limited

Habeyb, F. S, dkk. 1994. Everyday Antonymsand Synonyms. Jakarta: BhuanaIlmuPopuler Azar, Schrampher, Betty. 1990. Fundamental of English Grammar.Indonesia:Binapura Murphy. 1998. English Grammar in Use. United Kingdom: Cambridge University Press

Hornby, S. A. Eight Edition. 2010. Oxford Advanced Learner's Dictonary. New York: Oxford University Press

Richards, C. Jack, dkk. 1992. Longman Dictionary. United Kingdom: Longman Group UK limited 